\section{Mineralogy, Petrology, and Geochemistry of the Lunar Samples}

\author{
Arden L. Albee
}

On July 24, 1969, the first extraterrestrial samples, with the exception of meteorites, were returned to earth by Apollo 11. Since then these samples and the samples returned by Apollo 12 have been subjected to scientific investigations by hundreds of scientists from many countries. Drawing on advances from the last 25 years of study of meteorites and terrestrial rocks the variety and sophistication of the techniques used on these samples is truly impressive. It can truthfully be said that 10 years ago we could not have made the measurements, and that, even if we had had the data, we could not have interpreted it. The electron microprobe, the scanning electron microscope, and the mass spectrometer, as well as other instruments and techniques, have joined the microscope as routine tools with which to attack a petrologic problem.

Most of the results to date have been published in special issues or volumes that are referenced separately in the bibliography (with tables of contents). Basic data on the flights, on the sample collections, and on the experiments conducted on the lunar surface are contained in two National Aeronautics and Space Administration reports (Ref. B and Ref. F; see also Ref. A and Ref. E). The papers presented at the Apollo 11 Lunar Science Conference in January, 1970 are contained in a special issue of Science (Ref. C). Expanded and revised versions of most of these papers are contained in a three-volume, 2492-page supplement to Geochimica et Cosmochimica Acta (Ref. D). Fourteen papers describing Lunar Sample 12013 have been collected in a special issue of Earth and Planetary Science Letters (Ref. G). (The abbreviations Ref. A, .., Ref. $G$ replace the date in references to papers contained in these special compilations.)

Most of the basic observations, data, and conclusions summarized here were obtained by dozens of investigators. Hence, the references are included mainly to indicate a good starting point for further reading and are not inclusive.

The astronauts on the Apollo 11 and 12 missions did not sample bed rock. The returned lunar samples included large fragments of igneous rock and microbreccia collected on the lunar surface and samples of lunar soil.

The lunar soil is a diverse mixture of crystalline and glass fragments with a wide range of size. Most of the lithic fragments in the soil are similar to the larger

Arden L. Albee is with the Division of Geological Sciences, California Institute of Technology, Pasadena 91109. igneous rock samples and are probably derived from the underlying bed rock. However, some are totally different from the larger fragments and may represent samples from other parts of the moon. The abundance of anorthosite fragments has led a number of workers to infer that the lunar highlands are comprised of anorthosite and that the separation of plagioclase from the magma to form the highlands is a major lunar process [Smith, et al,, Ref. D, 937-956; Smith, et al:, 1970; Wood, et al., Ref. D, 965-988].

The glass fragments include regular forms, such as spheres and dumbbells, as well as broken fragments and irregular forms. Irregular splotches of glass represent splashes of molten silicate. Surfaces of both rock and glass fragments show beautifully preserved pits as small as a few microns in diameter, which are the result of impacts by tiny hypervelocity particles. Small fragments of meteorites have been found in the soil, but many of the pits may have formed in the hypervelocity stream of particles and melt droplets thrown out from larger impact features. The glass fragments shown a broad range in color and in chemical composition, which exceeds that of the larger igneous rocks. Broad studies of the soil materials include those of Carter and MacGregor [Ref. D, 247-266], Duke et al.. [Ref. D, 347-362], Frondel et al. [Ref. D, 445-474], Wood et al. [Ref. D, 965-988], and Wood et al. [1970].

The microbreccias are a mechanical mixture of rock and glass fragments, not unlike the soil, but are compacted or welded into a coherent rock. Like the soil, they also contain rock types not found among the larger igneous rock samples. A much smaller proportion of microbreccia samples was returned from the Apollo 12 site than from the Apollo 11 site.

The larger igneous rock fragments from the Apollo 11 site range from very fine-grained vesicular basalts to vuggy, medium-grained microgabbros with little difference in mineralogy. A summary description of the rock samples is given by Schmitt et al. [Ref. D, 1-54]. These rocks consist predominantly of Ti-rich augite, calcic plagioclase, and ilmenite with lesser amounts of olivine, cristobalite, troilite, Fe-metal, and an interstitial $\mathrm{K}$ - and Al-rich 'phase,' consisting predominantly of glass and fine-grained crystalline material [Roedder and Weiblen, Ref. D, 801-837]. The augite has a large range in composition, ranging in single crystals from about $\left(\mathrm{Ca}_{35} \mathrm{Fe}_{15} \mathrm{Mg}_{50}\right) \mathrm{SiO}_{3}$ to a $\left(\mathrm{Ca}_{13} \mathrm{Fe}_{85} \mathrm{Mg}_{2}\right) \mathrm{SiO}_{3} \mathrm{com}-$ position with a pyroxenoid structure. The augite also contains $2-10 \%$ of $\mathrm{CaTi}\left(\mathrm{Al}_{2} \mathrm{O}_{6}\right)$ end member and in some rocks the compositional range is further extended by exsolution of pigeonite. Plagioclase grains are fairly homogeneous with compositions ranging from about $\mathrm{An}_{75}$ to $\mathrm{An}_{98}$. A good introduction to the dozens of detailed papers on the petrology and mineralogy of the lunar igneous rocks is provided by Agrell et al. [Ref. D 81-86], Brown et al. [Ref. D, 195-220], Keil et al. [Ref. D, 561-598], Smith et al. [Ref. D, 897-926], Weill et al. [Ref. D, 937-956], or James and Jackson [1970].

Most of the igneous rocks returned from the Apollo 12 site are generally similar, but they exhibit a wider 
range of modal composition, grain size, and texture. Low-Ca pyroxenes and olivine are more abundant. Olivine vitrophyre contains skeletal olivine, which may represent subsolidus crystallization.

Minor minerals include zircon, baddeleyite, chlorofluoroapatite, whitlockite(?) high in rare earth elements, tridymite, quartz, K-feldspar, various spinels, metallic copper, pseudobrookite, and dysanalyte (?). Armalcolite (a ferropseudobrookite), pyroxferroite (an iron-analog of pyroxmangite), and several spinels of unusual composition are new minerals unknown in terrestrial rocks [Anderson et al., Ref. D, 55-64; Chao et al., Ref. D, 65-80; Agrell et al., Ref. D, 81-86].

Melting experiments on silicate melts with chemical compositions similar to the Apollo 11 rocks indicate that the major mineral phases crystallized from an igneous melt in a narrow $\left(\sim 75^{\circ} \mathrm{C}\right)$ temperature interval within the temperature range $1210^{\circ}$ to $1075^{\circ} \mathrm{C}$; minor interstitial liquids continued to crystallize down to at least $1045^{\circ} \mathrm{C}$ [Smith et al, 1970; O'Hara et al., Ref. D, 695-710; Roedder and Weiblen, Ref. D, 801-837; Ringwood and Essene, Ref. D, 769-800]. Microscopic and microprobe examination clearly demonstrates that an interstitial residual liquid persisted, which was rich in $\mathrm{Si}, \mathrm{K}, \mathrm{Al}$, and various minor elements and which was probably immiscible with the main melt [Roedder and Weiblen, Ref. D, 801-837]. An immiscible sulfide liquid, from which the troilite and metallic iron crystallized, probably separated during the later stages of crystallization [Skinner, Ref. D, 894].

Viscosities are much lower and densities are much higher for lunar magmas than for typical terrestrial basaltic magmas [Weill et al., Ref. D, 937-956; Murase and McBirney, 1970]. These differences are significant to an understanding of the textural feature and magmatic differentiation in the lunar rocks and of the morphological features of the lunar surface. For example, owing to low viscosity and high density, an individual lava flow may form a very thin cover over a considerable portion of a mare surface.

Experiments indicate that the observed phases could have coexisted only in a very dry, highly reducing system. The partial pressure of oxygen is estimated as $10^{-16}$ atm [Smith et al., Ref. D, 917), 5 orders of magnitude lower than that for typical terrestrial basaltic magmas. The low level of ferric iron in pyroxenes, determined by Mössbauer spectroscopy and electron spin resonance, the presence of troilite and native iron, and the occurrence of the unusual spinel compositions are further evidence of the low oxidation state of the magmas. The silicate minerals are highly transparent and clear owing to the complete lack of any hydrous alteration or weathering. No minerals have been shown to contain hydroxyl. D/H measurements indicate that the bulk of the $\mathrm{H}$ is of solar-wind origin and that it is most likely that the lunar surface is nearly devoid of primary water [Epstein and Taylor, Ref. D, 1091]. Vesicles and vugs are common features in the lunar rocks, but the composition of the volatile phase is not known. Despite the abundance of troilite, calculations indicate that vesiculation due primarily to $S_{2}$ pressure is unlikely [Weill et al., Ref. D, 949-950].

Experiments at high pressures and temperatures show that the Apollo 11 rocks would have densities at relatively shallow depths that fa- exceed the density of the moon [Ringwood and Essene, Ref. D, 769-799]. Hence, as predicted by Wetherill [1968], rocks with the composition of the Apollo 11 rocks cannot represent the bulk composition of the moon and must represent a derivative of some more primative material.

The chemical composition of the Apollo 11 igneous rocks is not grossly unlike that of terrestrial basalts, but the $\mathrm{Fe}$ and $\mathrm{Ti}$ content is distinctly higher and the $\mathrm{Na}$ content distinctly lower than occurs in typical terrestrial basalts. The compositions are quite uniform, but differ in the content of certain trace elements not abundant in the major minerals. The content of these 'incompatible' trace elements divides the rocks into two distinct groups with $\mathrm{K}$ differing by a factor of $4.4, \mathrm{Rb}$ by $7.7, \mathrm{Ba}$ by 3.0 , Ce by $2.1, \mathrm{Zr}$ by $1.5, \mathrm{Hf}$ by $1.6, \mathrm{U}$ by 4.1 , and $\mathrm{P}$ by 2.0 [Gast et al., Ref. D, 1151]. Each of these groups is so similar chemically and isotopically that it appears likely that only two igneous bodies were sampled on the Apollo 11 mission. Compared with terrestrial basalts, they are all richer in refractory elements such as $\mathrm{Ba}, \mathrm{Y}$, $\mathrm{Ti}$, Hf, Ta, Th, U, and trivalent rare earth elements, lower in alkalies, lower in volatile and chalcophile elements such as $\mathrm{Bi}, \mathrm{Hg}, \mathrm{Zn}, \mathrm{Cd}, \mathrm{Tl}, \mathrm{Pb}, \mathrm{Ge}$, and $\mathrm{Br}$, and lower in most siderophile elements including $\mathrm{Co}, \mathrm{Ir}, \mathrm{Ni}$, $\mathrm{Pd}$, and $\mathrm{Au}$ [Ganapathy et al., Ref. D, 1133]. The pattern of the rare earth elements is similar to that in chondritic meteorites, but is distinguished by a marked depletion of Eu relative to other rare earths. This has been attributed to extensive separation of plagioclase [Philpotts and Schnetzler, Ref. D, 1471-1486].

The chemical compositions of rocks from the A pollo 12 site differ in detail, but show these same characteristics and correspond most closely to the low-K group.

The chemical composition of the soils and breccias contains many of the distinctive characteristics of the igneous rocks, but elemental and isotopic abundances clearly indicate that it contains at least two other components. Enrichment in $\mathrm{Ni}$ and in elements characteristic of carbonaccous chondrites, such as $\mathrm{Cd}, \mathrm{Zn}, \mathrm{Ag}$, $\mathrm{Au}, \mathrm{Cu}$, and $\mathrm{Tl}$, indicate a maximum meteoritic contribution of 1-2\% [Ganapathy et al., Ref. D, 1117-1142]. Another component is high in 'incompatible' elements [Goles et al., Ref. D, 1177-1194] and corresponds closely to the difference in composition between the two Apollo 11 rock groups, to the composition of the interstitial, residual-liquid phase of the basalts, and to several exotic fragments that have been described, notably rock 12013 (see Ref. G) and Luny Rock \#1 [Albee et al., Ref. C, 463-465, Albee and Chodos, Ref. D, 135-158].

Model $\mathrm{Sr} / \mathrm{Rb}$ ages for the soil are much older than the ages of the rock fragments contained within it and indicate the presence of a component with a high $\mathrm{Rb} / \mathrm{Sr}$ ratio with a model age of $4.6 \times 10^{9}$ years. Similarly model $\mathrm{Pb}-\mathrm{U}-\mathrm{Th}$ ages also indicate the presence of an ancient component with high $\mathrm{Pb}-\mathrm{U}-\mathrm{Th}$ contents.

Rock 12013 (described in Ref. G) is important 
because it has many of the characteristics of these soil components and it provides clear evidence of the existence and importance of K-, Rb-, U-, Th-rich granitic rocks and magmatic reservoirs in the early history of the moon. Rock 12013 contains the highest Si content and 10-50 times more $\mathrm{K}, \mathrm{Rb}, \mathrm{Li}, \mathrm{Ba}, \mathrm{Y}, \mathrm{Zr}, \mathrm{Th}, \mathrm{U}$, and rare earth elements than other lunar rocks. It is an extremely heterogeneous fragmental rock that has been permeated by a once-fluid granitic component, consisting dominantly of potassic feldspar and quartz. This granitic component has a high $\mathrm{Rb} / \mathrm{Sr}$ and a model age of about $4.5 \times 10^{9}$ years. The existence of this rock and similar exotic fragments, taken in conjunction with the soil composition, indicates that such rocks will be found elsewhere on the moon and that they are important to our understanding of the early differentiation history of the moon.

Rock 12013 is also important in finally ruling out a lunar origin for tektites [Taylor and Epstein, Ref. G, 208-210]. Although it has an $\mathrm{SiO}_{2}$ content that is in the same range as that of some tektites, the oxygen isotopic values are totally outside the range of values for tektites.

No simple process can produce a melt with the distinctive characteristics of the lunat rocks from any known terrestrial rock or meteorite compositions. Volatile and alkali element loss in heating, gross separation of metal and sulfide phases, and silicate melt-solid differentiation must all be important [Ringwood and Essene, Ref. D, 769-799; Ganapathy et al., Ref. D, 1117-1142].

The $\mathrm{Rb} / \mathrm{Sr}$ isotopic data on the soil and on these exotic fragments strongly suggest that the distinctive chemical patterns were present almost at the beginning of the moon's history [Lunatic Asylum, Ref. G, 137-163], and, taken together with other geochemical data, appear to rule out a fission origin. Models involving accretion in a planet-satellite system, with the accretion dependent on temperature, the mass of the bodies, or both, have been proposed to account for many of these characteristics [Ringwood and Essene, Ref. D, 769-800; Ganapathy et al., Ref. D, 1117-1142].

However, the isotopic, chemical, and petrological data require, in addition, rapid differentiation of a lunar crust at $4.5 \times 10^{9}$ years and a mechanism for melt formation at $3.3 \times 10^{9}, 3.6 \times 10^{9}$, and possibly 4.0 $\times 10^{9}$ years. It is not yet clear whether the necessary heat source is internal, from long-lived radioactivities, or external, by very large scale impact. Nor is it yet clear whether the entire moon has been differentiated or only its outer shell.

A large number of important studies, which do not fall directly into petrologic, mineralogic, and geochemical categories, were performed on the lunar samples and are included in References $C$ and $D$. The studies of physical properties are important to the interpretation and extension of telescopic observations, seismic experiments, and magnetic measurements. Rocks on the lunar surface serve as a monitor of radiation from both the galaxy and the sun, and detailed studies have provided new information on lunar surface processes, the cosmic- ray flux, and the solar wind. The intensive search for complex carbon compounds of protobiological significance and for viable organisms produced negative results, and most of the observed carbon appears to be of solar-wind origin.

Although collected from only two locations, the Apollo samples have given a vast new insight into the processes that formed the moon and shaped its surface. The results do not resolve the problem of the origin of the moon. However, significant limits have been established for the chemical parameters, on the time, and on the rate of many processes. A large number of constraints must now be met by any theory that attempts to explain the origin of the moon.

\section{BIBLIOGRAPHY}

\section{Reference $A$}

Lunar Sample Preliminary Examination Team, Preliminary examination of lunar samples from Apollo 11, Science, 165 , 1211-1227, 1969.

\section{Reference $B$}

National Aeronautics and Space Administration, Apollo 11 preliminary science report, NASA SP-214, 204 pp., 1969. Contents below.

Hess, W. N., and A. J. Calio, Summary of scientific results, 1. Sasser, J. H., Photographic summary of Apollo 11 mission, 9.

Aldrin, E. E., Jr., N. A. Armstrong, and M. Collins, Crew observations, 35 .

Shoemaker, E. M., N. G. Bailey, R. M. Batson, D. H. Dahlem, T. H. Foss, M. J. Grolier, E. N. Goddard, M. H. Hait, H. E. Holt, K. B. Larson, J. J. Rennilson, G. G. Schaber, D. L. Schleicher, H. H. Schmitt, R. L. Sutton, G. A. Swann, A. C. Waters, and M. N. West, Geologic setting of the lunar samples returned by the Apollo 11 mission, 41.

Costes, N. C., W. D. Carrier, J. K. Mitchell, and R. F. Scott, Apollo 11 soil mechanics investigation, 85 .

Preliminary examination of lunar samples, 123.

Latham, G. V., M. Ewing, F. Press, G. Sutton, J. Dorman, N. Toksöz, R. Wiggins, Y. Nakamura, J. Derr, and F. Duennebier, Passive seismic experiment, 143.

Alley, C. O., P. L. Bender, R. F. Chang, D. G. Currie, R. H. Dicke, J. E. Faller, W. M. Kaula, G. J. F. MacDonald, J. D. Mulholland, H. H. Plotkin, S. K. Poultney, D. T. Wilkinson, I. Winer, W. Carrion, T. Johnson, P. Spadin, L. Robinson, E. J. Wampler, D. Wieber, E. Silverberg, C. Steggerda, J. Mullendore, J. Rayner, W. Williams, B. Warner, H. Richardson, and B. Bopp, Laser ranging retroreflector, 163.

Giess, J., P. Eberhardt, P. Signer, F. Buehler, and J. Meister, The solar-wind composition experiment, 183.

Lunar surface closeup stereoscopic photography, 187.

Bates, J. R., S. C. Freden, and B. J. O'Brien, The modified dust detector in the early Apollo scientific experiments package, 199.

\section{Reference $C$}

Science, Apollo 11 and Lunar Science Conference, Science, 167, 449-784, 1970. Contents below.

Lunar Sample Analysis Planning Team, Summary of Apollo 11 Lunar Science Conference, 449.

Shoemaker, E. M., M. H. Hait, G. A. Swann, D. L. Schleicher, D. H. Dahlem, G. G. Schaber, and R. L. Sutton, Lunar regolith at Tranquillity base, 452 .

Latham, G. V., M. Ewing, F. Press, G. Sutton, J. Dorman, Y. 
Nakamura, N. Toksöz, R. Wiggins, J. Derz, and F. Duennebier, Passive scismic experiment, 455 .

Alley, C. O., R. F. Chang, D. G. Currie, S. K. Poultney, P. L. Bender, R. H. Dicke, D. T. Wilkinson, J. E. Faller, W. M. Kaula, G. J. F. MacDonald, J. D. Mulholland, H. H. Plotkin, W. Carrion, and E. J. Wampler, Laser ranging retro-reflector: Continuing measurements and expected results, 458.

Tatsumoto, M., and J. N. Rosholt, Age of the moon: An isotopic study of uranium- thorium-lead systematics of lunar samples, 461.

Albee, A. L., D. S. Burnett, A. A. Chodos, O. J. Eugster, J. C. Huneke, D. A. Papanastassiou, F. A. Podosek, G. Price Russ II, H. G. Sanz, F. Tera, and G, J. Wasserburg, Ages, irradiation history, and chemical composition of lunar rocks from the Sea of Tranquillity, 463 .

Turner, G., Argon-40/argon-39 dating of lunar rock samples, 466.

Silver, L. T., Uranium-thorium-lead isotope relations in lunar materials, 468 .

Gopalan, K., S. Kaushal, C. Lee-Hu, and G. W. Wetherill Rubidium-strontium, uranium, and thorium-lead dating of lunar material, 471.

Hurley, P. M., and W. H. Pinson, Jr., Rubidium-strontium relations in Tranquiltity base samples, 473 .

Compston, W., P. A. Arriens, M. J. Vernon, and B. W. Chappell, Rubidium-strontium chronology and chemistry of lunar material, 474 .

Murthy, V. R., R. A. Schmitt, and P. Rey, Rubidium-strontium age and elemental and isotopic abundances of some trace elements in lunar samples, 476

Wanless, R. K., W. D. Loveridge, and R. D. Stevens, Age determinations and isotopic abundance measurements on lunar samples, 479.

Kohman, T. P., L. P. Black, H. Ihochi, and J. M. Huey, Lcad and thallium isotopes in Mare Tranquillitatis surface material, 481.

Gast, P. W., and N. J. Hubbard, Abundance of alkali metals, alkaline and rare earths, and strontium-87/strontium- 86 ratios in lunar samples, 485 .

Haskin, L. A., P. A. Helmke, and R. O. Allen, Rare earth elements in returned lunar samples, 487.

Keays, R. R., R. Ganapathy, J. C. Laul, E. Anders, G. F. Herzog, and $P$. M. Jeffery, Trace elements and radioactivity in lunar rocks: Implications for meteorite infall, solar-wind flux, and formation conditions of moon, 490.

Philpotts, J. A., and C. C. Schnetzler, Potassium, rubidium, strontium, barium, and rare-earth concentrations in lunar rocks and separated phases, 493.

Moore, C. B., C. F. Lewis, E. K. Gibson, and W. Nichiporuk, Total carbon and nitrogen abundances in lunar samples, 495.

Goleš, G. G., M. Osawa, K. Randle, R. L. Beyer, D. Y. Jerome, D. J. Lindstrom, M. R. Martin, S. M. McKay, and T. L. Steinborn, Instrumental neutron activation analyses of lunar specimens, 497.

Fields, P. R., H. Diamond, D. N. Metta, C. M. Stevens, D. J. Rokop, and P. E. Moreland, Isotopic abundances of actinide elements in lunar material, 499.

Reed, G. W., Jr., S. Jovanovic, and L. H. Fuchs, Trace elements and accessory minerais in lunar samples, 501 .

Baedecker, P. A., and J. T. Wasson, Gallium, germanium, indium, and iridium in lunar samples, 503 .

Morrison, G. H., J. T. Gerard, A. T. Kashuba, E. V. Gangadharam, A. M. Rothenberg, N. M. Potter, and G. B. Miller, Multielement analysis of lunar soil and rocks, 505 .

Turekian, K. K., and D. P. Kharkar, Neutron activation analysis of milligram quantities of lunar rocks and soils, 507 .

Smales, A. A., D. Mapper, M. S. W. Webb, R. K. Webster, and J. D. Wilson, Elemental composition of lunar surface material, 509.

Schmitt, R. A., H. Wakita, and P. Rey, Abundances of 30 elements in lunar rocks, soil, and core samples, 512 .

Richardson, K. A., D. S. McKay, W. R. Greenwood, and T. H. Foss, Alpha-particle activity of Apollo 11 samples, 516 .

Ware, N. G., and J. F. Lovering, Electron-microprobe analyses of phases in lunar samples, 517.
Rose, H. J., Jr., F. Cuttitta, E. J. Dwornik, M. K. Carron, R. P. Christian, J. R. Lindsay, D. T. Ligon, and R. R. Larson, Semimicro chemical and X-ray fluorescence analysis of lunar samples, 520.

Annell, C., and A. Helz, Emission spectrographic determination of trace elements in lunar samples, 521 .

Wänke, H., F. Begemann, E. Vilcsek, R. Rieder, F. Teschke, W. Born, M. Quijano-Rico, H. Voshage, and F. Wlotzka, Major and trace elements and cosmic-ray produced ratioisotopes in lunar samples, 523

Engel, A. E. J., and C. G. Engel, Lunar rock compositions and some interpretations, 527.

Ehmann, W. D., and J. W. Motgan, Oxygen, silicon, and aluminum in lunar samples by 14 Mev neutron activation, 528 .

Maxwell, J. A., S. Abbey, and W. H. Champ, Chemical composition of lunar material, 530 .

Wiik, H. B., and P. Ojanpera, Chemical analyses of lunar samples 10017,10072 , and 10084,531 .

Peck, L. C., and V. C. Smith, Quantitative chemical analysis of lunar samples, 532 .

Epstein, S., and H. P. Taylor, Jr., ${ }^{18} \mathrm{O} /{ }^{16} \mathrm{O},{ }^{30} \mathrm{Sj} /{ }^{28} \mathrm{Si}, \mathrm{D} / \mathrm{H}$, and ${ }^{13} \mathrm{C} /{ }^{12} \mathrm{C}$ studies of lunar rocks and minerals, 533 .

Onuma, N., R. N. Clayton, and T. K. Mayeda, Oxygen isotope fractionation between minerals and an estimate of the temperature of formation, 536 .

Friedman, I., J. R. O'Neil, L. H. Adami, J. D. Gleason, and K. Hardcastle, Water, hydrogen, deuterium, carbon, carbon-13, and oxygen-18 content of selected lunar matcrial, 538 .

Kaplan, I. R., and J. W. Smith, Concentration and isotopic composition of carbon and sulfur in Apollo 11 lunar samples, 541.

Hintenberger, H., H. W. Weber, H. Voshage, H. Wänke, F. Begemann, E. Vilscek, and F. Whotzka, Rare gases, hydrogen, and nitrogen: Concentrations and isotopic composition in lunar material, 543.

Reynolds, J. H., C. M. Hohenberg, R. S. Lewis, P. K. Davis, and W. A. Kaiser, Isotopic analysis of rare gases from stepwise heating of lunar fines and rocks, 545 .

Marti, K., G. W. Lugmair, and H. C. Urey, Solar wind gases, cosmic ray spallation products, and the irradiation history, 548.

Pepin, R. O., L. E. Nyquist, D. Phinney, and D. C. Black, Isotopic composition of rare gases in lunar samples, 550 .

Stoenner, R. W., W. J. Lyman, and R. Davis, Jr., Cosmic ray production of rare gas radioactivities and tritium in lunar material, 553.

Heymann, D., A. Yaniv, J. A. S. Adams, G. E. Fryer, Inert gases in lunar samples, 555.

Eberhardt, P., J. Geiss, H. Graf, N. Grögler, U. Krăhenbuhl, H Schwaller, J. Schwarzmütler, A. Stettler, Trapped solar wind noble gases, $\mathrm{Kr}^{81} / \mathrm{Kr}$ exposure ages and $\mathrm{K} / \mathrm{Ar}$ ages in Apollo 11 lunar material, 558.

Funkhouser, J. G., O. A. Schaeffer, D. D. Bogard, and J. Zahringer, Gas analysis of the lunar surface, 561 .

Crozaz, G., U. Haack, M. Hair, H. Hoyt, J. Kardos, M. Maurette, M. Miyajima, M. Seitz, S. Sun, R. Walker, M. Wittels, and D. Woolum, Solid state studies of the radiation history of the lunar samples, 563.

Fireman, E. L., J. D'Amico, and J. C. DeFelice, Tritium and argon radioactivities in lunar material, 566.

Fleischer, R. L., E. L. Haincs, R. E. Hanneman, H. R. Hart, Jr. J. S. Kasper, E. Lifshin, R. T. Woods, and P. B. Price, Particle track, X-ray, thermal, and mass spectrometric studies of lunar material, 568.

Kirsten, T., F. Steinbrunn, and J. Zahringer, Rare gases in lunar samples: Study of distribution and variations by a microprobe technique, 571 .

Shedlovsky, J. P., M. Honda, R. C. Reedy, J. C. Evans, Jr., D. Lal, R. M. Lindstrom, A. C. Delany, J. R. Arnold, H.-H. Loosli, J. S. Fruchter, and R. C. Finkel, Pattern of bombardmentproduced radionuclides in rock 10017 and in lunar soil, 574.

Perkins, R. W., L. A. Rancitelli, J. A. Cooper, J. H. Kayc, and N. A. Wogman, Cosmogenic and primordial radionuclides in lunar samples by nondestructive gamma-ray spectrometry, 577 . 
O'Kelley, G. D., J. S. Eldridge, E. Schonfeld, and P. R. Bell, Elemental compositions and ages of lunar samples by nondestructive gamma-ray spectrometry, 580 .

Agrell, S. O., J. H. Scoon, I. D. Muir, J. V. P. Long, J. D. C. McConnell, and A. Peckett, Mineralogy and petrology of some lunar samples, 583 .

Anderson, A. T., A. V. Crewe, J. R. Goldsmith, P. B. Moore, J. C. Newton, E. J. Olsen, J. V. Smith, and P. J. Wyllie, Petrologic history of moon suggested by petrography, mineralogy, and crystallography, 587.

Adler, I., L. S. Walter, P. D. Lowman, B. P. Glass, B. M. French, J. A. Philpotts, K. J. F. Heinrich, and J. I. Goldstein, Electron microprobe analysis of lunar samples, 590 .

Bailey, J. C., P. E. Champness, A. C. Dunham, J. Esson, W. S. Fyfe, W. S. MacKenzie, E. F. Stumpfl, and J. Zussman, Mineralogical and petrological investigations of lunar samples, 592.

Douglas, J. A. V., M. R. Dence, A. G. Plant, and R. J. Traill, Mineralogy and deformation in some lunar samples, 594 .

Keil, K., M. Prinz, and T. E. Bunch, Mineral chemistry of lunar samples, 597.

Brown, G. M., C. H. Emeleus, J. G. Holland, and R. Phillips, Petrographic, mineralogic, and X-ray fluorescence analysis of lunar igneous-type rocks and spherules, 599.

Wood, J. A., J. S. Dickey, Jr., U. B. Marvin, and B. N. Powell, Lunat anorthosites, 602 .

O'Hara, M. J., G. M. Biggar, and S. W. Richardson, Experimental petrology of lunar material: The nature of mascons, seas, and the lunar interior, 605 .

Ringwood, A. E., and E. Essene, Petrogenesis of lunar basalts and the internal constitution and origin of the moon, 607.

Kushiro, I., Y. Nakamura, H. Haramura, and S.-I. Akimoto, Crystallization of some lunar mafic magmas and generation of rhyolitic liquid, 610 .

Haggerty, S. E., F. R. Boyd, P. M. Bell, L. W. Finger, and W. B. Bryan, Iron-titanium oxides and olivine from 10020 and 10071,613 .

Ramdohr, P., and A. El Goresey, Opaque minerals of the lunar rocks and dust from Mare Tranquillitatis, 615 .

Jedwab, J., A. Herbosch, R. Wollast, G. Naessens, and N. Van Geen-Peers, Search for magnetite in lunar rocks and fines, 618.

Simpson, P. R., and S. H. U. Bowie, Quantitative optical and electron-probe studies of the opaque phases, 619 .

Evans, H. T., Jr., Lunar troilite: Crystallography, 621.

Cameron, E. N., Opaque minerals in lunar samples, 623

Gay, P., G. M. Bancroft, and M. G. Bown, Diffraction and Mossbauer studies of minerals from lunar soils and rocks, 626 .

Ross, M., A. E. Bence, E. J. Dwornik, J. R. Clark, and J. J.

Papike, Lunar clinopyroxenes: Chemical composition, structural state, and texture, 628 .

Hargraves, R. B., L. S. Hollister, and G. Otalora, Compositional zoning and its significance in pyroxenes from three coarsegrained lunar samples, 631 .

Stewart, D. B., D. E. Appleman, J. S. Huebner, and J. R. Clark, Crystallography of some lunar plagioclases, 634.

Weill, D. F., I. S. McCallum, Y. Bottinga, M. J. Drake, and G. A McKay, Petrology of a fine-grained igneous rock from the Sea of Tranquillity, 635.

Radcliffe, S. V., A. H. Heuer, R. M. Fisher, J. M. Christie, and D. T. Griggs, High-voltage transmission electron microscopy study of lunar surface material, 638 .

Roedder, E., and P. W. Wiblen, Silicate liquid immiscibility in lunar magmas, evidenced by melt inclusions in lunar rocks, 641.

Chao, E. C. T., O. B. James, J. A. Minkin, J. A. Boreman, E. D. Jackson, and C. B. Raleigh, Petrology of unshocked crystalline rocks and shock effects in lunar rocks and minerals, 644 .

Duke, M. B., C. C. Woo, M. L. Bird, G. A. Sellers, and R. B. Finkelman, Lunar soil: Size distribution and mineralogical constituents, 648 .

King, E. A., Jr., M. F. Carman, and J. C. Butler, Mineralogy and petrology of coarse particulate material from lunar surface at Tranquillity base, 650 .
Skinner, B. J., High crystallization temperatures indicated for igneous rocks from Tranquillity base, 652 .

McKay, D. S., W. R. Greenwood, and D. A. Morrison, Morphology and related chemistry of small lunar particles from Tranquillity base, 654 .

Mason, B., K. Fredriksson, E. P. Henderson, E. Jarosewich, W. G Melson, K. M. Towe, and J. S. White, Jr., Mineralogy and petrography of lunar samples, 656 .

Arrhenius, G., S. Asunmaa, J. I. Drever, J. Everson, R. W. Fitzgerald, J. Z. Frazer, H. Fujita, J. S. Hanor, D. Lal, S. S Liang, D. Macdougall, A. M. Reid, J. Sinkankas, and L. Wilkening, Phase chemistry, structure, and radiation effects in lunar samples, 659 .

Carter, J. L., and I. D. MacGregor, Mineralogy, petrology, and surface features of lunar samples 10062,35, 10067,9, 10069,30 , and $10085,16,661$.

Fredriksson, K., J. Nelen, W. G. Melson, E. P. Henderson, and C. A. Andersen, Lunar glasses and micro-breccias: Properties and origin, 664 .

Carter, N. L., I. S. Leung, and H. G. Ave'Lallemant, Deformation of silicates from the Sea of Tranquillity, 666.

von Engelhardt, W., J. Arndt, W. F. Muller, and D. Stoffler, Shock metamorphism in lunar samples, 669.

Quaide, W., T. Bunch, and R. Wrigley, Impact metamorphism of lunar surface materials, 671 .

Short, N. M., Evidence and implications of shock metamorphism in lunar samples, 673 .

Sclar, C. B., Shock-wave damage in minerals of lunar rocks, 675.

Sippel, R. F., and A. B. Spencer, Cathodoluminescence properties of lunar rocks, 677.

Frondel, C., C. Klein, Jr., J. Ito, and J. C. Drake, Mineralogy and composition of lunar fines and selected rocks, 681 .

Herzenberg, C. L., and D. L. Riley, Mossbauer spectrometry of lunar samples, 683 .

Fernández-Morản, H., S. S. Hafner, M. Ohtsuki, and D. Virgo, Mossbauer effect and high-voltage electron microscopy of pyroxenes in type B samples, 686 .

Muir, A. H., Jr., R. M. Housley, R. W. Grant, M. Abdel-Gawad, and M. Blander, Mossbauer spectroscopy of moon samples, 688 .

Strangway, D. W., E. E. Larson, and G. W. Pearce, Magnetic properties of lunar samples, 691 .

Helsley, C. E., Magnetic properties of lunar dust and rock samples, 693.

Doell, R. R., C. S. Grommé, A. N. Thorpe, and F. E. Senftle, Magnetic studies of lunar samples, 695 .

Runcorn, S. K., D. W. Collinson, W. O'Reilly, A. Stephenson, N. N. Greenwood, and M. H. Battey, Magnetic properties of lunar samples, 693.

Larochelle, A., and E. J. Schwarz, Magnetic properties of lunar sample $10048-22,700$.

Alvarez, L. W., P. H. Eberhard, R. R. Ross, and R. D. Watt, Search for magnetic monopoles in the lunar samples, 701 .

Nagata, T., Y. Ishikawa, H. Kinoshita, M. Kono, Y. Syono, and R. M. Fisher, Magnetic properties of the lunar crystalline rock and fines, 703

Weeks, R. A., A. Chatelain, J. L. Kolopus, D. Kline, and J. G. Castle, Magnetic resonance properties of some lunar material, 704.

Gold, T., M. J. Campbell, and B. T. O'Leary, Optical and high-frequency electrical properties of the lunar sample, 707.

Manatt, S. L., D. D. Ellemen, R. W. Vaughan, S. I. Chan, F.-D. Tsay, and W. T. Huntress, Jr., Magnetic resonance studies of lunar samples, 709.

Dalrymple, G. B., and R. R. Doell, Thermoluminescence of lunar samples, 713.

Edgington, J. A., and I. M. Blair, Luminescence and thermoluminescence induced by bombardment with protons of 159 million electron volts, 715 .

Geake, J. E., A. Dollfus, G. F. J. Garlick, W. Lamb, C. Walker, G. A. Steigmann, and C. Titulaer, Luminescence, electron paramagnetic resonance, and optical properties of lunar material, 717.

Greenman, N. N., and H. G. Gross, Luminescence of Apollo 11 
lunar samples, 720

Nash, D. B., J. E. Conel, and R. T. Greer, Luminescence and reflectance of Tranquillity samples: Effects of irradiation and vitrification, 721 .

Birkebak, R. C., C. J. Cremers, and J. P. Dawson, Thermal radiation properties and thermal conductivity of lunar material, 724.

Kanamori, H., A. Nur, D. Chung, D. Wones, and G. Simmons Elastic wave velocities of lunar samples at high pressures and their geophysical implications, 726.

Bastin, J. A., P. E. Clegg, and G. Fielder, Infrared and thermal properties of lunar rock, 728 .

Horai, K.I., G. Simmons, H. Kanamori, and D. Wones, Thermal diffusivity and conductivity of lunar material, 730 .

Stephens, D. R., and E. M. Lilley, Compressibilities of lunar crystalline rock, microbreccia, and fines to 40 kilobars, 731 .

Schreiber, E., O. L. Anderson, N. Soga, N. Warren, and C. Scholz, Sound velocity and compressibility for lunar rocks 17 and 46 and for glass spheres from the lunar soil, 732 .

Fryxell, R., D. Anderson, D. Carrier, W. Greenwood, and G. Heiken, Apollo 11 drive-tube core samples: An initial physical analysis of lunar surface sediment, 734.

Adams, J. B., and R. L. Jones, Spectral reflectivity of lunar samples, 737.

Costes, N. C., W. D. Carrier, and R. F. Scott, Apollo 11 soil mechanics investigation, 739 .

Tolansky, S., Interferometric examination of small glassy spherules and related objects in a 5-gram lunar dust sample, 742.

Grossman, J. J., J. A. Ryan, N. R. Mukherjee, and M. W. Wegner, Surface properties of lunar samples, 743 .

Hapke, B. W., A. J. Cohen, W. A. Cassidy, and E. N. Wells, Solar radiation effects in lunar samples, 745

Herr, W., U. Herpers, B. Hess, B. Skerra, and R. Woelfle Determination of manganese-53 by neutron activation and other miscellaneous studies on lunar dust, 747 .

Robie, R. A., B. S. Hemingway, and W. H. Wilson, Specific heats of lunar surface materials from 90 to 350 degrees Kelvin, 749.

Burlingame, A. L., M. Calvin, J. Han, W. Henderson, W. Reed, and B. R. Simoneit, Lunar organic compounds: Search and characterization, 751 .

Meinschein, W. G., E. Cordes, and V. J. Shiner, Jr., Search for alkanes of 15 to 30 carbon atom length, 753 .

Rho, J. H., A. 'J. Bauman, T. F. Yen, and J. Bonner, Fluorometric examination of a lunar sample, 754.

Murphy, R. C., G. Preti, M. M. Nafissi-V., and K. Biemann, Search for organic material in lunar fines by mass spectrometry, 755 .

Abell, P. I., G. H. Draffan, G. Eglinton, J. M. Hayes, J. R. Maxwell, and C. T. Pillinger, Organic analysis of the returned lunar sample, 757 .

Johnson, R. D., and C. C. Davis, Pyrolysis-hydrogen flame ionization detection of organic carbon in a lunar sample, 759.

Ponnam peruma, C., K. Kvenvolden, S. Chang, R. Johnson, G. Pollock, D. Philpott, I. Kaplan, J. Smith, J. W. Schopf, C. Gehrke, G. Hodgson, I. A. Breger, B. Halpern, A. Duffield, K. Krauskopf, E. Barghoorn, H. Holland, and K. Keil, Search for organic compounds in the lunar dust from the Sea of Tranquillity, 760

Hodgson, G. W., E. Peterson, K. A. Kvenvolden, E. Bunnenberg, B. Halpern, and C. Ponnamperuma, Search for porphyrins in a lunar dust, 763 .

Oro, J., W. S. Updegrove, J. Gibert, J. McReynolds, E. Gil-Av, J. Ibanez, A. Zlatkis, D. A. Flory, R. L. Levy, and C. Wolf, Organogenic elements and compounds in surface samples from the Sea of Tranquillity, 765 .

Fox, S. W., K. Harada, P. E. Hare, G. Hinsch, and G. Mueller, Bio-organic compounds and glassy microparticles in lunar fines and other materials, 767 .

Nagy, B., C. M. Drew, P. B. Hamilton, V. E. Modzeleski, M. E. Murphy, W. M. Scott, H. C. Urey, and M. Young, Organic compounds in lunar samples: Pyrolysis products, hydrocarbons, amino acids, 770 .

Oyama, V. I., E. L. Merek, and M. P. Silverman, A search for viable organisms in a lunar sample, 773 .

Barghoorn, E. S., D. Philpott, and C. Turnbill, Micropaleontological study of lunar material, 775 .

Cloud, P., S. V. Margolis, M. Moorman, J. M. Barker, G. R. Licari, D. Krinsley, and V. E. Barnes, Micromorphology and surface characteristics of lunar dust and breccia, 776.

Lipsky, S. R., R. J. Cushley, C. G. Horvath, and W. J. McMurray, Analysis of lunar material for organic compounds, 778

Schopf, J. W., Micropaleontological studies of lunar samples, 779

\section{Reference $D$}

Geochimica et Cosmochima Acta, Supplement 1, Proceedings of the Apollo 11 Lunar Science Conference, edited by A. A. Levinson, 2492 pp., Pergamon Press, New York, 1970. Contents below.

Schmitt, H. H., G. Lofgren, G. A. Swann, and G. Simmons: The Apollo 11 samples: Introduction, 1.

Anderson, A. T., F. R. Boyd, T. E. Bunch, E. N. Cameron, A. El Goresy, L. W. Finger, S. E. Haggerty, O. B. James, K. Keil, M. Prinz, and P. Ramdohr, Armalcolite: A new mineral from the Apollo 11 samples, 55 .

Chao, E. C. T., J. A. Minkin, C. Frondel, C. Klein, Jr., J. C. Drake, L. Fuchs, B. Tani, J. V. Smith, A. T. Anderson, P. B. Moore, G. R. Zechman, Jr., R. J. Traill, A. G. Plant, J. A. V. Douglas, and M. R. Dence, Pyrox-ferrite, a new calciumbearing iron silicate from Tranquillity base, 65 .

Agrell, S. O., F. R. Boyd, T. E. Bunch, E. N. Cameron, M. R. Dence, J. A. V. Douglas, S. E. Haggerty, O. B. James, K. Keil, A. Peckett, M. Prinz, A. G. Plant, and R. J. Traill, Titanian chromite, aluminian chromite, and chromian ulvöspinel from A pollo 11 rocks, 81 .

Adler, I., L. S. Walter, P. D. Lowman, B. P. Glass, B. M. French, J. A. Philpotts, K. J. F. Heinrich, and J. I. Goldstein: Electron microprobe analysis of Apollo 11 lunar samples, 87

Agrell, S. O., J. H. Scoon, I. D. Muir, J. V. P. Long, J. D. McConnell, and A. Peckett, Observations on the chemistry, mineralogy, and petrology of some Apollo 11 lunar samples, 93.

Akimoto, S., Y. Nakamura, M. Nishikawa, T. Katsura, and I. Kushiro, Melting experiments of lunar crystalline rocks, 129.

Albee, A. L., and A. A. Chodos, Microprobe investigations on Apollo 11 samples, 135 .

Andersen, C. A., J. R. Hinthorne, and K. Fredriksson, Ion microprobe analysis of lunar material from Apollo 11, 159.

Bailey, J. C., P. E. Champness, A. C. Dunham, J. Esson, W. S. Fyfe, W. S. MacKenzie, E. F. Stumpfl, and J. Zussman, Mineralogy and petrology of Apollo 11 lunar samples, 169.

Brown, G. M., C. H. Emeleus, J. G. Holland, and R. Phillips, Mineralogical, chemical, and petrological features of Apollo 11 rocks and their relationship to igneous processes, 195.

Cameron, E. N., Opaque minerals in certain lunar rocks from Apollo 11, 221.

Carter, J. L., and I. D. MacGregor, Mineralogy, petrology and surface features of some Apollo 11 samples, 247.

Carter, N. L., Irene S. Leung, H. G. Ave'Lallemant, and L. Fernandez, Growth and deformational structures in silicates from Mare Tranquillitatis, 167.

Chao, E. C. T., Odette B. James, Jean A. Minkin, Judith A. Boreman, E. D. Jackson, and C. B. Raleigh, Impact metamorphic effects in lunar samples from Tranquillity base, 287.

Dence, M. R., J. A. V. Douglas, A. G. Plant, and R. J. Traill, Petrology, mineralogy and deformation of Apollo 11 samples, 315

Drever, J. I., R. W. Fitzgerald, S. S. Liang, and G. Arrhenius, Phyllosilicates in A pollo 11 samples, 341.

Duke, M. B., C. C. Woo, G. A. Sellers, M. L. Bird, and R. B. Finkelman, Genesis of lunar soil at Tranquillity base, 347.

von Engelhardt, W., J. Arndt, W. F. Müller, and D. Stöffler, Shock metamorphism of lunar rocks and origin of the regolith at the Apollo 11 landing site, 363.

Essene, E. J., A. E. Ringwood, and N. G. Ware, Petrology of the 
lunar rocks from Apollo 11 landing site, 385.

Evans, H. T., Jr., The crystallography of lunar troilite, 399.

Fernández-Morán, H., M. Ohtsuki, S. S. Hafner, and D. Virgo, High-voltage electron microscopy and electron diffraction of lunar pyroxenes, 409

Fredriksson, K., J. Nelen, and W. G. Melson, Petrography and origin of lunar breccias and glasses, 419.

French, B. M., L. S. Walter, and K. J. F. Heinrich, Quantitative mineralogy of an Apollo 11 lunar sample, 433.

Frondel, C., C. Klein, Jr., J. Ito, and J. C. Drake, Mineralogical and chemical studies of Apollo 11 lunar fines and selected rocks, 445 .

Fuchs, L. H., Fluorapatite and other accessory minerals in Apollo 11 rocks, 475

Gay, P., G. M. Bancroft, and M. G. Bown, Diffraction and Mössbauer studies of minerals from lunar soils and rocks, 481 .

Goldstein, J. I., E. P. Henderson, and H. Yakowitz, Investigation of lunar metal particles, 499 .

Haggerty, S. E., F. R. Boyd, P. M. Bell, L. W. Finger, and W. B. Bryan, Opaque minerals and olivine in lavas and breccias from Mare Tranquillitatis, 513.

Haramura, H., Y. Nakamura, and I. Kuṣhiro, Composition of lunar fines, 539.

Hollister, L. S., and R. B. Hargraves, Compositional zoning and its significance in pyroxenes from two coarse-grained Apollo 11 samples, 541.

Jedwab, J., and A. Herbosch, Tentative estimation of the contribution of Type 1 carbonaceous meteorites to the lunar soil, 551.

Keil, K., T. E. Bunch, and M. Prinz, Minrealogy and composition of Apollo 11 lunar samples, 561.

King, E. A., Jr., M. F. Carman, and J. C. Butler, Mineralogy and petrology of coarse particulate material from the lunar surface at Tranquillity base, 599 .

Kushiro, I., and Y. Nakamura, Petrology of some lunar crystalline rocks, 607

Lovering, J. F., and J. D. Kleeman, Fission track uranium distribution studies on Apollo 11 lunar samples, 627

Lovering, J. F., and N. G. Ware, Electron-probe microanalyses of minerals and glasses in A pollo 11 lunar samples, 633

Mason, B., K. Fredriksson, E. P. Henderson, E. Jarosewich, W. G. Melson, K. M. Towe, and J. S. White, J., Mineralogy and petrography of lunar samples, 655 .

Mason, B., and W. G. Melson, Comparison of lunar rocks with basalts and stony meteorites, 661 .

McKay, D. S., W. R. Greenwood, and D. A. Morrison, Origin of small lunar particles and breccia from the Apollo 11 site, 673 .

O'Hara, M. J., G. M. Biggar, S. W. Richardson, C. E. Ford, and B. G. Jamieson, The nature of seas, mascons, and the lunar interior in the light of experimental studies, 695.

Quaide, W., and T. Bunch, Impact metamorphism of lunar surface materials, 711

Radcliffe, S. V., A. H. Heuer, R. M. Fisher, J. M. Christie, and D. T. Griggs, High voltage $(800 \mathrm{kv})$ electron petrography of Type B rock from Apollo 11, 731 .

Reid, A. M., J. Z. Frazer, H. Fujita, and J. E. Everson: Apollo 11 samples: Major mineral chemistry, 749.

Richardson, K. A., D. S. McKay, W. R. Greenwood, and T. H. Foss, Alpha-particle activity of Apollo 11 samples, 763.

Ringwood, A. E., and E. Essene, Petrogenesis of Apollo 11 basalts, internal constitution and origin of the moon, 769.

Roedder, E., and P. W. Weiblen, Lunar petrology of silicate melt inclusions, A pollo 11 rocks, 801 .

Ross, M., A. E. Bence, E. J. Dwornik, J. R. Clark, and J. J. Papike, Mineralogy of the lunar clinopyroxenes, augite and pigeonite, 839.

Sclar, C. B., Shock metamorphism of lunar rocks and fines from Tranquillity base, 849 .

Short, N. M., Evidence and implications of shock metamorphism in lunar samples, 865 .

Simpson, P. R., and S. H. U. Bowie, Quantitative optical and electron-probe studies of opaque phases in Apollo 11 samples, 873.

Skinner, B. J., High crystallization temperatures indicated for igneous rocks from Tranquillity base, 891 .

Smith, J. V., A. T. Anderson, R. C. Newton, E. J. Olsen, A. V. Crewe, M. S. Isaacson, D. Johnson, and P. J. Wyllie, Petrologic history of the moon inferred from petrography, mineralogy and petrogenesis of Apollo 11 rocks, 897.

Stewart, D. B., D. E. Appleman, J. S. Huebner, and J. R. Clark, Crystallography of some lunar plagioclases, 927

Wanke, H., F. Wlotzka, E. Jagoutz, and F. Begemann, Composition and structure of metallic iron particles in lunar fines, 931.

Weill, D. F., I. S. McCallum, Y. Bottinga, M. J. Drake, and G. A McKay, Mineralogy and petrology of some Apollo 11 igneous rocks, 937.

Winchell, H., and B. J. Skinner, Glassy spherules from the lunar regolith returned by Apollo 11 expedition, 957.

Wood, J. A., J. S. Dickey, Jr., Ursula B. Marvin, B. N. Powell, Lunar anorthosites and a geophysical model of the moon, 965.

Annell, C. S., and A. W. Helz, Emission spectrographic determination of trace elements in lunar samples from Apollo 11 991.

Begemann, F., E. Vilcsek, R. Rieder, W. Born, and H. Wänke, Cosmic-ray produced radioisotopes in lunar samples from the Sea of Tranquillity (Apollo 11), 995.

Compston, W., B. W. Chappell, P. A. Arriens, and M. J. Vernon, The chemistry and age of Apollo 11 lunar material, 1007.

D'Amico, J., f. De Felice, and E. L. Fireman, The cosmic-ray and solar-flare bombardment of the moon, 1029.

Eberhardt, P., J. Geiss, H. Graf, N. Grögler, U. Krăhenbuhl, H. Schwaller, J. Schwarzmuller, and A. Stettler, Trapped solar wind noble gases, exposure age, and K/Ar-age in Apollo 11 lunar fine material, 1037.

Ehmann, W. D., and J. W. Morgan, Oxygen, silicon, and aluminum in Apollo 11 rocks and fines by $14 \mathrm{Mev}$ neutron activation, 1071.

Engel, A. E. J., and C. G. Engel, Lunar rock compositions and some interpretations, 1081.

Epstein, S., and H. P. Taylor, Jr., The concentration and isotopic composition of hydrogen, carbon, and silicon in Apollo 11 lunar rocks and minerals, 1085 .

Fields, P. R., H. Diamond, D. N. Metta, C. M. Stevens, D. J. Rokop, and P. E. Moreland, Isotopic abundances of actinide elements in lunar materials, 1097.

Friedman, I., J. D. Gleason, and K. Hardcastle, Water, hydrogen, deuterium, carbon, and ${ }^{13} \mathrm{C}$ content of selected lunar material, 1103.

Funkhouser, J, G., O. A. Schaeffer, D. D. Bogard, and J. Zahringer, Gas analysis of the lunar surface, 1111.

Ganapathy, R., R. R. Keays, J. C. Laul, and E. Anders, Trace elements in Apollo 11 lunar rocks: Implications for meteorite influx and origin of moon, 1117.

Gast, P. W., N. J. Hubbard, and H. Wiesmann, Chemical composition and petrogenesis of basalts from Tranquillity base, 1143 .

Goles, G. G., K. Randle, M. Osawa, R. A. Schmitt, H. Wakita, W. D. Ehmann, and J. W. Morgan, Elemental abundances by instrumental activation analyses in chips from 27 lunar rocks, 1165.

Goles, G. G., K. Randle, M. Osawa, D. J. Lindstrom, D. Y. Jerome, T. L. Steinborn, R. L. Beyer, M. R. Martin, and S. M. McKay, Interpretations and speculations on elemental abundances in lunar samples, 1177 .

Gopalan, K., S. Kaushal, C. Lee-Hu, and G. W. Wetherill, Rb-Sr and $\mathrm{U}, \mathrm{Th}-\mathrm{Pb}$ ages of lunar materials, 1195 .

Hanneman, R. E., Thermal and gas evolution behavior of Apollo 11 samples, 1207

Haskin, L. A., R. O. Allen, P. A. Helmke, T. P. Paster, M. R. Anderson, R. L. Korotev, and Kathleen A. Zweifel, Rareearths and other trace elements in Apollo 11 lunar samples, 1213.

Herr, W., U. Herpers, B. Hess, B. Skerra, and R. Woelfle, Determination of manganese- 53 by neutron activation and other miscellaneous studies on lunar dust, 1233 .

Herzog, G. F., and G. F. Herman, $\mathrm{Na}^{22}, \mathrm{Al}^{26}$, Th, and $\mathrm{U}$ in Apollo 11 lunar samples, 1239.

Heymann, D., and A. Yaniv, Inert gases in the fines from the Sea 
of Tranquillity, 1247.

Heymann, D., and A. Yaniv, $\mathrm{Ar}^{40}$ anomaly in lunar samples from Apollo 11, 1261.

Hintenberger, H., H. W. Weber, H. Voshage, H. Wânke, F. Begemann, and F. Wlotzka, Concentrations and isotopic abundances of the rare gases, hydrogen and nitrogen in lunar matter, 1269.

Hohenberg, C. M., P. K. Davis, W. A. Kaiser, R. S. Lewis, and J. $H$. Reynolds, Trapped and cosmogenic rare gases from stepwise heating of Apollo 11 samples, 1283.

Hurley, P. M., and W. H. Pinson, $\mathrm{J}_{\mathrm{r}}$, Whole-rock Rb-Sr isotopic age relationships in Apollo 11 lunar samples, 1311.

Kaplan, I. R., J. W. Smith, and E. Ruth, Carbon and sulfur concentration and isotopic composition in Apollo 11 lunar samples, 1317.

Kirsten, T., O. Muller, F. Steinbrunn, and J. Zähringer, Study of distribution and variations of rare gases in lunar material by a microprobe technique, 1331.

Kohman, T. P., L. P. Black, H. Ihochi, and J. M. Huey, Lead and thallium isotopes in Mare Tranquillitatis surface material, 1345.

Lovering, J. F., and D. Butterfield, Neutron activation analysis of rhenium and osmium in Apollo 11 lunar material, 1351.

Marti, K., G. W. Lugmair, and H. C. Urey, Solar wind gases, cosmic-ray spallation products, and the irradiation history of A pollo 11 samples, 1357.

Maxwell, J. A., L. C. Peck, and H. B. Wiik, Chemical composition of Apollo 11 lunar samples 10017, 10020, 10072, and $10084,1369$.

Moore, C. B., E. K. Gibson, J. W. Larimer, C. F. Lewis, and W. Nichiporuk, Total carbon and nitrogen abundances in Apollo 11 lunar samples and selected achondrites and basalts, 1375 .

Morrison, G. H., J. T. Gerard, A. T. Kashuba, E. V. Gangadharam, Ann M. Rothenberg, N. M. Potter, and G. B. Miller, Elemental abundances of lunar soil and rocks, 1383.

Murthy, V. R., N. M. Evensen, and M. R. Coscio, Jr., Distribution of $\mathrm{K}, \mathrm{Rb}, \mathrm{Sr}$, and $\mathrm{Ba}$ and $\mathrm{Rb}-\mathrm{Sr}$ isotopic relations in Apollo 11 lunar samples, 1393.

O'Kelley, G. D., J. S. Eldridge, E. Schonfeld, and P. R. Bell, Primordial radionuclide abundances, solar proton and cosmic ray effects and ages of Apollo 11 lunar samples by nondestructive gamma-ray spectrometry, 1407 .

O'Neil, J. R., and L. H. Adami, Oxygen isotope analyses of selected A pollo 11 materials, 1425.

Onuma, N., R. N. Clayton, and T. K. Mayeda, Apollo 11 rocks: Oxygen isotope fractionation between minerals, and an estimate of the temperature, 1429.

Pepin, R. O., L. E. Nyquist, D. Phinney, and D. C. Black, Rare gases in Apollo 11 lunar material, 1435.

Perkins, R. W., L. A. Rancitelli, J. A. Cooper, J. H. Kaye, and N. A. Wogman, Cosmogenic and primordial radionuclide measurements in Apollo 11 lunar samples by nondestructive analysis, 1455.

Philpotts, J. A., and C. C. Schnetzler, Apollo 11 lunar samples: $\mathrm{K}, \mathrm{Rb}, \mathrm{Sr}, \mathrm{Ba}$, and rare-earth concentrations in some rocks and separated phases, 1471

Reed, G. W., Jr., and S. Jovanovic, Halogens, mercury, lithium, and osmium in Apollo 11 samples, 1487.

Rose, H. J., Jr., F. Cuttitta, E. J. Dwornik, M. K. Carron, R. P. Christian, J. R. Lindsay, D. T. Ligon, and R. R. Larson, Semimicro X-ray fluorescence analysis of lunar samples, 1493.

Rosholt, J. N., and M. Tatsumoto, Isotopic composition of uranium and thorium in Apollo 11 samples, 1499.

Shedlovsky, J. P., M. Honda, R. C. Reedy, J. C. Evans, Jr., D. Lal, R. M. Lindstrom, A. C. Delany, J. R. Arnold, H. H. Loosli, J. S. Fruchter, and R. C. Finkel, Pattern of bombardmentproduced radionuclides in rock 10017 and in lunar soil, 1503 .

Silver, L. T., Uranium-thorium-lead isotopes in some Tranquillity base samples and their implications for lunar history, 1533.

Smales, A. A., D. Mapper, M. S. W. Webb, R. K. Webster, and J. D. Wilson, Elemental composition of lunar surface material, 1575 .

Stoenner, R. W., W. J. Lyman, and R. Davis, Jr., Cosmic-ray production of rare-gas radioactivities and tritium in lunar material, 1583.

Tatsumoto, M., Age of the moon: An isotopic study of U-Th-Pb systematics of Apollo 11 lunar samples, 2, 1595.

Taylor, H. P., Jr., and S. Epstein, $\mathrm{O}^{18} / \mathrm{O}^{16}$ ratios of Apollo 11 lunar rocks and minerals, 1613.

Taylor, S. R., P. H. Johnson, R. Martin, D. Bennett, J. Allen, and W. Nance, Preliminary chemical analyses of Apollo 11 lunar samples, 1627.

Tera, F., O. Eugster, D. S. Burnett, and G. J. Wasserburg, Comparative study of $\mathrm{Li}, \mathrm{Na}, \mathrm{K}, \mathrm{Rb}, \mathrm{Cs}, \mathrm{Ca}, \mathrm{Sr}$, and $\mathrm{Ba}$ abundances in achondrites and in Apollo 11 lunar samples, 1637.

Turekian, K. K., and D. P. Kharkar, Neutron activation analysis of milligram quantities of Apollo 11 lunar rocks and soil, 1659 .

Turner, G., Argon-40/argon-39 dating of lunar rock samples, 1665.

Wakita, H., R. A. Schmitt, and P. Rey, Elemental abundances of major, minor, and trace elements in Apollo 11 lunar rocks, soil and core samples, 1685 .

Wanke, H., R. Rieder, H. Baddenhausen, B. Spettel, F. Teschke, M. Quijano-Rico, and A. Balacescu, Major and trace elements in lunar material, 1719.

Wanless, R. K., W. D. Loveridge, and R. D. Stevens, Age determinations and isotopic abundance measurements of lunar samples (Apollo 11), 1729.

Wasson, 3. T., and P. A. Baedecker, Ga, Ge, Ir, and Au in lunar, terrestrial, and meteoritic basalts, 1741 .

Wrigley, R. C., and W. L. Quaide, $\mathrm{Al}^{26}$ and $\mathrm{Na}^{22}$ in lunar surface materials: Implications for depth distribution studies, 1751.

Abell, P. I., C. H. Draffan, G. Eglinton, J. M. Hayes, J. R. Maxwell, and C. T. Pillinger: Organic analysis of the returned Apollo 11 lunar samples, 1757.

Barghoorn, E. S., Micropaleontological study of lunar material from Apollo 11, 1775.

Burlingame, A. L., M. Calvin, J. Han, W. Henderson, W. Reed and B. R. Simoneit, Study of carbon compounds in Apollo 11 lunar samples, 1779 .

Cloud, P., S. V. Margolis, Mary Moorman, J. M. Barker, G. Licari, D. Krinsley, and V. E. Barnes, Micromorphology and surface characteristics of lunar dust and breccia, 1793.

Hare, P. E., K. Harada, and S. W. Fox, Analyses for amino aeids in lunar fines, 1799.

Johnson, R. D., and Catherine C. Davis, Total organic carbon in the Apollo 11 lunar samples, 1805.

Kvenvolden, K. A., S. Chang, J. W. Smith, J. Flores, K. Pering, C. Saxinger, F. Woeller, K. Keil, I. Breger, and C. Ponnamperuma, Carbon compounds in lunar fines from Mare Tranquillitatis, 1 , Search for molecules of biological significance, 1813.

Hodgson, G. W., E. Bunnenberg, B. Halpern, Etta Peterson, K. A. Kvenvolden, and C. Ponnamperuma, Carbon compounds in lunar fines from Mare Tranquillitatis, 2, Search for porphyrins, 1829.

Gehrke, C. W., R. W. Zumwalt, W. A. Aue, D. L. Stalling, A. Duffield, K. A. Kvenvolden, and C. Ponnamperuma, Carbon compounds in lunar fines from Mare Tranquillitatis, 3, Organosiloxanes in the hydrochloric acid hydrolysates, 1845 . Chang, S., J. W. Smith, I. Kaplan, J. Lawless, K. A. Kvenvolden, and C. Ponnamperuma, Carbon compounds in lunar fines from Mare Tranquillitatis, 4, Evidence for oxides and carbides, 1857.

Lipsky, S. R., R. J. Cushley, G. G. Horvath, and W. J. McMurray, Analysis of lunar material for organic compounds, 1871.

Meinschein, W. G., T. J. Jackson, J. M. Mitchell, E. Cordes, and V. J. Shiner, Jr., Search for alkanes of 15-30 carbon atom length in lunar fines, 1875 .

Murphy, Sister Mary E., V. E. Modzeleski, B. Nagy, W. M. Scott, M. Young, C. M. Drew, P. B. Hamilton, and H. C. Urey, Analysis of Apollo 11 lunar samples by chromatography and mass spectrometry: Pyrolysis products, hydrocarbons, sulfur amino acids, 1879.

Murphy, R. C., G. Preti, M. M. Nafissi-V, and K. Biemann, Search for organic material in lunar fines by mass spectrometry, 1891. 
Oró, J., W. S. Updegrove, J. Gibert, J. McReynolds, E. Gil-av, J. lbanez, A. Zlatkis, D. A. Flory, R. L. Levy, and C. J. Wolf Organogenic elements and compounds in Type $\mathrm{C}$ and $\mathrm{D}$ lunar samples from Apollo 11, 1901.

Oyama, V. I., E. L. Merek, and M. P. Silverman, A search for viable organisms in a lunar sample, 1921.

Rho, J. H., A. J. Bauman, Teh Fu Yen, and J. Bonner, Fluorometric examination of the returned lunar fines from Apollo 11, 1929.

Schopf, J. W., Micropaleontological studies of Apollo 11 lunar samples, 1933.

Adams, J. B., and T. B. McCord, Remote sensing of lunar surface mineralogy: Implications from visible and near-infrared reflectivity of Apollo 11 samples, 1937.

Alley, C. O., R. F. Chang, D. G. Currie, S. K. Poultney, P. L. Bender, R. H. Dicke, D. T. Wilkinson, J. E. Faller, W. M Kaula, G. J. F. MacDonald, J. D. Mulholland, H. H. Plotkin, W. Carrion, and E. J. Wampler, Laser-ranging retro-reflector: Continuing measurements and expected results, 1947.

Alvarez, L. W., P. H. Eberhard, R. R. Ross, and R. D. Watt, Search for magnetic monopoles in the lunar samples of Apollo $11,1953$.

Anderson, O. L., C. Scholz, N. Soga, N. Warren, and E. Schreiber, Elastic properties of a micro-breccia, igneous rock, and lunar fines from Apollo $11 \mathrm{~m}$ ission, 1959.

Asunmaa, S. K., S. S. Liang, and G. Arrhenius, Primordial accretion: Inferences from the lunar surface, 1975 .

Bastin, J. A., P. E. Clegg, and G. Fielder, Infrared and thermal properties of lunar rock, 1987.

Birkebak, R, C., C. J. Cremers, and J. P. Dawson, Directional spectra and total reflectance of lunar material, 1993.

Blair, I. M., and J. A. Edgington, Luminescence and thermoluminescence under $159 \mathrm{Mev}$ proton bombardment of the lunar material returned by Apollo 11, 2001.

Conel, J. E., and D. B. Nash, Spectral reflectance and albedo of Apollo 11 lunar samples: Effects of irradiation and vitrification and comparison with telescopic observations, 2013.

Costes, N. C., and J. K. Mitchell, Apollo 11 soil mechanics investigation, 2025

Cremers, C. J., R. C. Birkebak, and J. P. Dawson, Thermal conductivity of fines from Apollo 11, 2045.

Crozaz, G., U. Haack, M. Hair, M. Maurette, R. Walker, and D. Woolum, Nuclear track studies of ancient solar radiations and dynamic lunar surface processes, 2051.

Dalrymple, G. B., and R. R. Doell, Thermoluminescence of lunar samples from Apollo 11, 2081.

Doell, R. R., and C. S. Grommé, Survey of magnetic properties of Apollo 11 samples at the Lunar Receiving Laboratory, 2093.

Doell, R. R., C. S. Grommé, A. N. Thorpe, and F. E. Senftle, Magnetic studies of A pollo 11 lunar samples, 2097.

Fleischer, R. L., E. L. Haines, H. R. Hart, Jr., R. T. Woods, and G. M. Comstock: The particle track record of the Sea of Tranquillity, 2103.

Fryxell, R., D. Anderson, D. Carrier, W. Greenwood, and G. Heiken, Apollo 11 drive-tube core samples: an initial physical analysis of lunar surface sediment, 2121.

Geake, J. E., A Dollfus, G. F. J. Garlick, W. Lamb, G. Walker, G. A. Steigmann, and C. Titulaer, Luminescence, electron paramagnetic resonance and optical properties of lunar material from Apollo 11, 2127.

Gold, T., M. J. Campbell, and B. T. O'Leary, Optical and high-frequency electrical properties of the lunar sample, 2149.

Greenman, N. N., and H. G. Gross, Luminescence studies of Apollo 11 lunar samples, 2155.

Greenwood, N. N., and A. T. Howe, Mössbauer studies of Apollo 11 lunar samples, 2163.

Grossman, J. J., J. A. Ryan, N. R. Mukherjee, and M. W. Wegner, Microchemical, microphysical and adhesive properties of lunar material, 2171.

Hafner, S. S., and D. Virgo, Temperature-dependent cation distributions in lunar and terrestrial pyroxenes, 2183.

Hapke, B. W., A. J. Cohen, W. A. Cassidy, and E. N. Wells, Solar radiation effects on the optical properties of Apollo 11 samples, 2199

Helsley, C. E., Magnetic properties of lunar 10022, 10069, 10084 , and 10085 samples, 2213.

Herzenberg, C. L., and D. L. Riley, Analysis of first returned lunar samples by Mossbauer spectrometry, 2221.

Horai, K., G. Simmons, H. Kanamori, and D. Wones, Thermal diffusivity, conductivity, and thermal inertia of Apollo 11 lunar material, 2243.

Housley, R. M., M. Blander, M. Abdel-Gawad, R. W. Grant, and A. H. Muir, Jr., Mössbauer spectroscopy of Apollo 11 samples, 2251

Hoyt, H. P., Jr, J. L. Kardos, M. Miyajima, M. G. Seitz, S. S. Sun, R. M. Walker, and M. C. Wittels, Thermoluminescence, $\mathrm{X}$-ray, and stored energy measurements of Apollo 11 samples, 2269.

Kanamori, H., A. Nur, D. H. Chung, and G. Simmons, Elastic wave velocities of lunar samples at high pressures and their geophysical implications, 2289.

Lal, D., D. Macdougall, L. Wilkening, and G. Arrhenius, Mixing of the lunar regolith and cosmic ray spectra: Evidence from particle-track studies, 2295.

Larochelle, A., and E. J. Schwarz, Magnetic properties of Apollo 11 sample, 10048-22, 2305.

Latham, G. V., M. Ewing, F. Press, G. Sutton, J. Dorman, Y. Nakamura, N. Toksöz, R. Wiggins, J. Derr, and F. Duennebier, Apollo 11 passive seismic experiment, 2309.

Manatt, S. I., D. D. Elleman, R. W. Vaughan, S. I. Chan, F. D. Tsay, and W. T. Huntress, Jr., Magnetic resonance studies of lunar samples, 2321.

Nagata, T., Y. Ishikawa, H. Kinoshita, M. Kono, Y. Syono, and R. M. Fisher, Magnetic properties and natural remanent magnetization of lunar materials, 2325 .

Nash, D. B., and R. T. Greer, Luminescence properties of Apollo 11 lunar samples and implications for solar-excited lunar luminescence, 2341.

Price, P. B., and D. O'Sullivan, Lunar erosion rate and solar flate paleontology, 2351

Robie, R. A., B. S. Hemingway and W. H. Wilson, Specific heats of lunar surface materials from $90^{\circ}$ to $350^{\circ} \mathrm{K}, 2361$.

Runcorn, S. K., D. W. Collinson, W. O'Reilly, M. H. Battey, A. Stephenson, J. M. Jones, A. J. Manson, and P. W. Readman, Magnetic properties of Apollo 11 lunar samples, 2369.

Schwarz, E. J., Thermomagnetics of lunar dust sample 10084, $88,2389$.

Shoemaker, E. M., M. H. Hait, G. A. Swann, D. L. Schleicher, G. G. Schaber, R. L. Sutton, D. H. Dahlem, E. N. Goddard, and A. C. Waters, Origin of the lunar regolith at Tranquillity base, 2399.

Sippel, R. F., and A. B. Spencer, Luminescence petrography and properties of lunar crystalline rocks and breccias, 2413.

Stephens, D. R., and E. M. Lilley, Loading-unloading pressurevolume curves to $40 \mathrm{kbar}$ for lunar crystalline rock, microbreccia and fines, 2427 .

Strangway, D. W., E. E. Larson, and G. W. Pearce, Magnetic studies of lunar samples-breccia and fines, 2435 .

Thorpe, A. N., F. E. Senftle, S. Sullivan, and C. C. Alexander, Magnetic studies of individual glass spherules from the lunar sample 10084-86-2, Apollo 11, 2453.

Tolansky, S., Interferometric examination of small glassy spherules and related objects in a 5-gram lunar dust sample, 2463.

Weeks, R. A., J. L. Kolopus, D. Kline, and A. Chatelain, A pollo 11 lunar material: Nuclear magnetic resonance of ${ }^{27} \mathrm{Al}$ and electron resonance of $\mathrm{Fe}$ and $\mathrm{Mn}, 2467$.

\section{Reference $E$}

Lunar Sample Preliminary Examination Team, Preliminary examination of lunar samples from Apollo 12, Science, 167, $1325-1339,1970$.

\section{Reference $F$}

National Aeronautics and Space Administration, Apollo 12 
preliminary science report, NASA SP-235, 1970. Contents below.

Simmons, G., and A. J, Calio, Summary of scientific results, 1. Wade, L. C., Photographic summary of the Apollo 12 mission, 7. Bean, A. L., C. Conrad, Jr., and R. F. Gordon, Crew observations, 29.

Latham, G. V., M. Ewing, F. Press, G. Sutton, J. Dorman, Y. Nakamura, N. Toksoz, R. Wiggins, and R. Kovach, Passive seismic experiment, 39 .

Dyal, P., C. W. Parkin, and C. P. Sonett, Lunar surface magnetometer experiment, 55 .

Snyder, C. W., D. R. Clay, and M. Neugebauer, The solar-wind spectrometer experiment, 75 .

Freeman, J. W., Jr., H. Balsiger, and H. K. Hills, Suprathermal ion detector experiment (lunar ionosphere detector), 83 .

Johnson, F. S., D. E. Evans, and J. M. Carroll, Cold cathode gage (lunar atmosphere detector), 93 .

Geiss, J., P. Eberhardt, P. Signer, F. Buehler, and J. Meister, The solar-wind composition experiment, 99

Goetz, A. F. H., F. C. Billingsley, E. Yost, and T. B. McCord, Apollo 12 multispectral photography experiment, 103.

Shoemaker, E. M., R. M. Batson, A. L. Bean, C. Conrad, Jr., D. H. Dahlem, E. N. Goddard, M. H. Hait, K. B. Larson, G. G. Schaber, D. L. Schleicher, R. L. Sutton, G. A. Swann, and A. C. Waters, Preliminary geologic investigation of the Apollo 12 landing site, A, Geology of the Apollo 12 landing site, 113.

Holt, H. E., and J. J. Rennilson, Preliminary geologic investigation of the Apollo 12 landing site, B, Photometric and polarimetric properties of the lunar regolith, 157.

Scott, R. F., W. D. Carrier, N. C. Costes, and J. K. Mitchell, Preliminary geologic investigation of the Apollo 12 landing site, C, Mechanical properties of the lunar regolith, 161 .

Gold, T., F. Pearce, and R. Jones, Lunar surface closeup stereoscopic photography, 183.

The Lunar Sample Preliminary Examination Team, Preliminary examination of lunar samples, 189.

Benson, R. E., B. G. Cour-Palais, L. E. Giddings, Jr., S. Jacobs, P. H. Johnson, J. R. Martin, F. J. Mitchell, and K. A. Richardson, Preliminary results from Surveyor 3 analysis, 217.

\section{Reference $G$}

Earth and Planetary Science Letters, Issue especially devoted to the study of lunar sample 12013, Earth Planet. Sci. Lett., 9, $93-215,1970$. Contents below.

Anderson, D. H., Introduction: The preliminary examination and preparation of lunar sample 12013, 94.

Drake, M. J., I. S. McCallum, G. A. McKay, and D. F. Weill, Mineralogy and petrology of Apollo 12 sample no. 12013: A progess report, 103.

Gay, P., M. G. Bown, and K. O. Rickson, Mineralogical studies of lunar rock 12013, 10, 124.

Burnett, D. S., M. Monnin, M. Seitz, R. Walker, D. Woolum, and D. Yuhas, Charged particle track studies in lunar rock 12013, 2.

Lunatic Asylum, Mineralogic and isotopic investigations on lunar rock $12013,137$.

Morgan, J. W., and W. D. Ehmann, Lunar rock 12013, O, Si, Al, and $\mathrm{Fe}$ abundances, 164.

Wakita, H., and R. A. Schmitt, Elemental abundances in seven fragments from lunar rock $12013,169$.

Turner, G., ${ }^{40} \mathrm{Ar}^{39} \mathrm{Ar}$ age determination of lunar rock 12013, 177.

Hubbard, N. J., P. W. Gast, and H. Wiesmann, Rare earth, alkaline and alkati metal, and ${ }^{87} / 86 \mathrm{Sr}$ data for subsamples of lunar sample 12013, 181.

Schnetzler, C. C., J. A. Philpotts, and M. L. Bottino, Li, K, Rb, $\mathrm{Sr}, \mathrm{Ba}$, and rare-earth concentrations, and $\mathrm{Rb}-\mathrm{Sr}$ age of lunar rock 12013,185 .

Tatsumoto, M., U-Th-Pb age of Apollo 12 rock 12013, 193.

Alexander, E. C., Jr., Rare gases from stepwise heating of lunar rock $12013,201$.

Taylor, H. P., Jr., and S. Epstein, Oxygen and silicon isotope ratios of lunar rock 12013, 208.

Laul, J. C., R. Keays, R. Ganapathy, and E. Anders, Abundance of 14 trace elements in lunar rock 12013, 10, 211.

Ahrens, L. H., and R. V. Danchin, Lunar surface rocks and fines: Chemical composition, Science, 167, 87-88, 1970.

Anders, E., Water on the moon?, Science, 169, 1309-1310, 1970

Bence, A. E., J. J. Papike, and C. T. Prewitt, A pollo 12 clinopyroxenes: Chemical trends, Earth Planet. Sci. Lett., 8, 393--399, 1970.

Borg, J., J. C. Dran, L. Durrieu, C. Jouret, and M. Maurette, High voltage electron microscope studies of fossil nuclear particle tracks in extraterrestrial matter, Earth Planet. Sci. Lett., 8, $379-386,1970$

Dickey, J. S., Jr., Nickel-iron in lunar anorthosites, Earth Planet. Sci. Lett., 8, 387-392, 1970.

Eugster, O., F. Tera, D. S. Burnett, and G. J. Wasserburg, The isotopic composition of $\mathrm{Gd}$ and the neutron capture effects in samples from Apollo 11, Earth Planet. Sci. Lett., 8, 20-30, 1970 .

Fuchs, L. H., Orthopyroxene-plagioclase fragments in the lunar soil from Apollo 12, Science, 169, 866-867, 1970.

Franzgrote, E. J., J. H. Patterson, A. L. Turkevich, T. E. Economore, and K. P. Sowinski, Chemical composition of the lunar surface in Sinus Medii, Science, 167, 376-379, 1970.

Gibb, F. G. F., E. F. Stumpfl, and J. Zussman, Opaque minerals in an Apollo 12 rock, EArth Planet. Sci. Lett., 9, 217-224, 1970.

Gold, T., Origin of glass deposits in lunar craters, Science, 165 , $1345-1349,1969$.

Green, Origin of glass deposits in lunar craters, Science, 168, 608-609, 1970. (Discussions by; E. B. Dietz and P. J. Vergano, 609-610; W. R. Greenwood and G. Heiken, 610-611;T. Gold, 611.)

Heydegger, H. R., and A. Turkevich, Radioactivity induced in Apollo 11 lunar surface material by solar flare protons, Science, $168,575,1970$.

James, O. B., and Everett D. Jackson, Petrology of the Apollo 11 ilmenite basalts, J. Geophys. Res., 75, 5793-5822, 1970.

King, E. A., Jr., R. Martin, and W. B. Nance, Tektite glass not in Apollo 12 sample, Science, 170, 199-200. (Reply by J. A. O'Keefe, 200.)

Manka, R. H., and F. C. Michel, Lunar atmosphere as a source of argon-40 and other lunar surface elements, Science, 169 , $278-280,1970$.

Murase, Tsutomu, and A. R. McBirney, Viscosity of lunar lavas, Science, 170, 165-167, 1970 .

Murase, Tsutomu, and A. R. McBirney, Thermal conductivity of lunar and terrestrial igneous rocks in their melting range, Science, $170,165-167,1970$.

Neukurn, G., A. Mehl, H. Fechtig, and J. Zähringer, Impact phenomena of micrometeorites on lunar surface material, Earth Planet. Sci. Lett., 8, 31-35, 1970.

O'Keefe, J. A., Tektite glass in A pollo 12 sample, Science, 168 , $1209-1210,1970$.

Papanastassiou, D. A., G. J. Wasserburg, and D. S. Bumett, Rb-Sr ages of lunar rocks from the Sea of Tranquillity, EArth Planet. Sci. Lett., 8, 1-19, 1970 .

Patterson, J. H., A. L. Turkevich, E. J. Franzgrote, T. E. Economore, and K. P. Sowinski, Chemical composition of the lunar surface in a terra region near the Crater Tycho, Science, $168,825-828,1970$.

Reid, A. M., C. Meyer, Jr., R. S. Harmon, and R. Brett, Metal grains in Apollo 12 igneous rocks, Earth Planet. Sci. Lett., 9, $1-5,1970$.

Ringwood, A. E., Origin of the moon: The precipitation hypothesis, Earth Planet. Sci. Lett., 8, 131-140, 1970.

Schaeffer, O. A., J. G. Funkhouser, D. D. Bogard, and J. Zähringer, Potassium-argon age of lunar rocks from Mare Tranquillitatis and Oceanus Procellarum, Science, 170, $161-162,1970$. 
Schreiber, E., and O. L. Anderson, Properties and composition of lunar materials: Earth analogies, Science, 168, 1579-1580, 1970.

Singer, S. F., and L. W. Bandermann, Where was the moon formed? Science, 170, 438-439, 1970.

Smith, J. V., A. T. Anderson, R. C. Newton, E. J. Olsen, and P. J. Wyllie, A petrologic model for the moon based on petrogenesis, experimental petrology, and physical properties, J. Geol., 78, 381-405, 1970.

Traill, R. J., A. G. Plant, and J. A. V. Douglas, Garnet: First occurrence in the lunar rocks, Science, 169, 981-982, 1970.

Turkevich, A. L., E. J. Granzgrote, and J. H. Patterson, Chemical analysis of the moon at the Surveyor V landing site, Science, $158,635-637,1967$

\section{Radioactive and Radiogenic Isotope Research}

\author{
G. R. Tilton
}

The number of laboratories and workers in the field of radioactive isotope research has grown rapidly over the past four years. With this growth has come a large increase in the volume of literature on the subject. Consequently the bibliography, given below is meant to include the more significant or more complete investigations. The references are restricted to papers published by U.S. laboratories from approximately January 1967 through October 1970.

Extraterrestrial Studies. The availability of returned lunar material has stimulated many kinds of investigations. The great antiquity of lunar materials has been one of the most interesting findings from the first studies. The $\mathrm{Rb}-\mathrm{Sr}$ age of crystalline rocks from the Apollo 11 site on the Sea of Tranquillity is about 3.7 billion years [Papanastassiou et al., 1970; Gopalan et al., 1970; Hurley and Pinson, 1970], a value in close agreement with the highest K-Ar ages found by Funkhouser et al. [1970] and by G. Turner at Sheffield in some excellent ${ }^{40} \mathrm{Ar} /{ }^{39} \mathrm{Ar}$ dating. The isotopic lead ages [Tatsumoto, 1970a, $b ;$ Silver, 1970] are more difficult to interpret. The problem is partly that all leads found on the moon to date are highly radiogenic, making it difficult to know the proper initial lead correlation. Also the amount of common lead found in the rocks is so small that laboratory contamination may be critical to some interpretations. The lead ages are nearly concordant at 4.1 b.y. if initial lead corrections are based on primordial or modern terrestrial lead; however, Tatsumoto has shown how the data can be reconciled with ages of 3.4 to 3.8 b.y. on the basis of two-stage evolution models for the lead. Such models can remove the conflict with the $\mathrm{Rb}-\mathrm{Sr}$ and $\mathrm{K}-\mathrm{Ar}$ data.

G. R. Tilton is with the Department of Geological Sciences, University of California, Santa Barbara 93106.
Turkevich, A. J., J. H. Patterson, and E. J. Franzgrote, Chemical analysis of the moon at the Surveyor VI landing site: Preliminary results, Science, 160, 1108-1111, 1968.

Turkevich, A. J., E. J. Franzgrote, and J. H. Patterson, Chemical composition of the lunar surface in Mare Tranquillitatis, Science, 165, 277-279, 1969.

Ulbrich, M. C., Chemical individuality of lunar, meteoritic, and terrestrial silicate rocks, Science, 168, 1375-1376, 1970.

Wetherill, G. W., Lunar interior, constraint on basaltic composition, Science, 160,1256-1257, 1968.

Wood, J. A., U. B. Marvin, B. N. Powell, and J. S. Dickey, Jr., Mineralogy and petrology of the Apollo 11 lunar sample, Smithson. Astrophys. Observ. Spec. Rep. 307, 1970.

The data from the Apollo 11 dust and breccia yield a formal Rb-Sr isochron age of 4.6 b.y. [Papanastassiou et al., 1970], whereas the isotopic lead ages are nearly concordant at 4.7 b.y. [Tatsumoto, 1970b; Silver, 1970; Gopalan et al., 1970]. In spite of the close agreement of the two ages and their agreement with $\mathrm{Rb}$-Sr ages from meteorites (see below), it is not yet possible to state that the soil data record the age of the moon.

Few Apollo 12 data (Ocean of Storms) have appeared as yet. The $\mathrm{Rb}-\mathrm{Sr}$ age of the unusually high potassium rock 12013 is 4.0 b.y. [Lunatic Asylum, 1970; Schnetzler et al., 1970], whereas the isotopic lead age is about $3.9-4.0$ b.y., according to a two-stage lead evolution model [Tatsumoto, 1970a]. Turner reports ${ }^{40} \mathrm{Ar} /{ }^{39} \mathrm{Ar}$ ages of $3.9 \mathrm{~b} . \mathrm{y}$. for both light and dark phases of the rock.

D. A. Papanastassiou and G. J. Wasserburg (preprint) report $\mathrm{Rb}-\mathrm{Sr}$ ages of 3.3 b.y. for two crystalline rocks at the Apollo 12 site, and a Rb-Sr model age of 4.44 b.y. for dust. The younger crystalline rock ages at the A pollo 12 site, compared with the Apollo 11 site, may be reflected in the dust ages at the two sites, but the most impressive aspect of the ages is their general agreement.

Several important advances in meteorite studies merit special mention. $\mathrm{Rb}-\mathrm{Sr}$ isochrons have been determined for each of the various chondrite groups, H, L, LL, E, and C [Gopalan and Wetherill, 1968, 1969, 1970; Kaushal and Wetherill, 1969, 1970]. Their work relied almost entirely on falls to eliminate effects due to possible chemical alterations of finds. Ages varied from 4.48 to 4.69 b.y., analytical errors in each case being about \pm 0.15 b.y. The results are thus consistent with $\mathrm{Rb}-\mathrm{Sr}$ differentiation ages of 4.55 and $4.60 \mathrm{~b}$.y. for all the groups. Bogard et al. [1967] obtained a Rb-Sr age of $4.7 \pm 0.1$ b.y. for the Norton County achondrite, using separated fractions from the stone. This is one of very few stones for which satisfactory internal isochrons are measured. New data on the Rb-Sr ages of silicate inclusions are given by Burnett and Wasserburg [1967a, b]. Six irons yield ages of around 4.5 b.y., a value similar to the $\mathrm{Rb}-\mathrm{Sr}$ ages of stone meteorites but not in agreement with the older K-Ar ages that have been reported for the metal phase of iron meteorites. Rancitelli and Fisher [1968] believe that the older K-Ar ages result from potassium migration. Silicate inclusions from the Kodiakanal iron meteorite give a $\mathrm{Rb}-\mathrm{Sr}$ age of $3.8 \pm 0.1$ 